\title{
AFFORESTATION OF AGRICULTURAL LAND WITH PINUS RADIATA D. DON AND BETULA ALBA L. IN NW SPAIN: EFFECTS ON SOIL PH, UNDERSTOREY PRODUCTION AND FLORISTIC DIVERSITY ELEVEN YEARS AFTER ESTABLISHMENT
}

\author{
A. RIGUEIRO-RODRÍGUEZ1 ${ }^{1}$ M. R. MOSQUERA-LOSADA ${ }^{1 *}$ AND E. FERNÁNDEZ-NÚÑ̃EZ ${ }^{1,2}$ \\ ${ }^{1}$ Department of Crop Production, Escuela Politécnica Superior, Campus de Lugo, University of Santiago de Compostela, 27002 Galicia, Spain \\ ${ }^{2}$ Mountain Research Centre (CIMO), ESA - Instituto Politécnico de Bragança, Campus de Sta Apolónia, Apartado 1172, Bragança 53001-855, Portugal
}

Received 18 December 2009; Revised 21 October 2010; Accepted 22 October 2010

\begin{abstract}
Afforestation of abandoned agricultural lands has been the main change in land use over the past decade in Europe. However, the impact of tree species and understorey management on production and plant diversity over the medium- and long-term has not been thoroughly studied. This paper aims to evaluate the effects of an afforestation of Pinus radiata D. Don and Betula alba $\mathrm{L}$. on soil $\mathrm{pH}$, understorey production and plant diversity and life cycle type (annuals vs. perennials) managed with different soil fertilisation treatments over a period of 11 years. The results show an acidification of the soil 11 years after establishment, better vertical growth and diameter of pine compared with birch as usually happens in the region and important variation in the biomass production and composition of the understorey below both tree species. Understorey species remained similar during the first 5 years below both canopies. However, species richness $(S)$ was drastically reduced under Pinus radiata D. Don plantation compared to Betula alba L. $\left(S_{\text {pine }}=2\right.$ vs. $\left.S_{\text {birch }}=17\right)$ after 11 years of tree establishment at a very high density $\left(2500\right.$ trees ha $\left.^{-1}\right)$. Inorganic and organic fertilisation also caused a reduction in floristic diversity. Soil $\mathrm{pH}$, pasture production and floristic understorey plant diversity are better preserved under autochthonous broadleaves, which increased the multiple uses of recently afforested lands in the short- and medium-term. In the European context of high need for sawn wood, the use of autochthonous broadleaved tree species like Betula should be promoted due to their better sustainability. Copyright (C) 2011 John Wiley \& Sons, Ltd.
\end{abstract}

KEY WORDS: broadleaved; conifer; dairy cattle manure sludge; biosolid; Spain

\section{INTRODUCTION}

The EU has declared the ambitious objective of stopping the loss of biodiversity in Europe by 2010 (Official Journal of the European Communities, 2002), being change in land use one of the main management causes of biodiversity reduction (Aguiar, 2005). Intensification of agriculture as well as monospecific silviculture and the propagation of non-autochthonous and generalist species are some of the key factors responsible for the soil nutrient status changes, understorey productivity and loss of plant diversity (Augusto et al., 2002) in EU forests and agricultural lands all over the world. Since the middle of the 20th century, policies of afforestation and increasing timber production have been imposed in the EU, resulting in the planting of large areas of productive coniferous tree species and a reduction in native deciduous species area (EC, 2004) as happened with Pinus

* Correspondence to: M. R. Mosquera-Losada, Department of Crop Production, Escuela Politécnica Superior, Campus de Lugo, University of Santiago de Compostela, Galicia, Spain.

E-mail: mrosa.mosquera.losada@usc.es radiata in other continents like South America (Paritsis and Aizen, 2008) or Oceania (Brockerhoff et al., 2001). Exotic Conifer tree plantations usually cause important changes in soil fertility, understorey production and plant diversity (Michelsen et al., 1996; Frank and Finckh, 1997; Raffaele and Schlichter, 2000) compared with native broadleaved species due to their different canopy type, light interception and structure (Brockerhoff et al., 2001). Generally, these new forest areas aim to produce timber, which is initially and partly delivered in the first thinning several decades after planting. The use of silvopastoral systems is considered a tool to enhance plant diversity through sympathetic management to indigenous diversity (Brockerhoff et al., 2001), while increasing forestry farm profitability (Sibbald, 1996; Fernández-Núñez et al., 2007), as intermediate products (wool, meat) are delivered at the same time that tree growth is occurring. Moreover, in Galicia, one of the regions of Europe most prone to forest fires, herbaceous layer promotion through the establishment of silvopastoral systems help to reduce fire risk (Rigueiro-Rodríguez et al., 2009), and to protect forest biodiversity. 
Reforestation of Agricultural Land (Regulation EEC $\mathrm{n}^{\circ}$ 2080/1992 $n^{\circ} 1257 / 1999$ ) caused an increase of 400000 ha of afforested areas in the Galicia region in the 1990s (MAPA, 2006), mostly with exotic and fast growing species like Eucalyptus spp. and Pinus radiata D. Don. The latter is the species used most often in afforestation in the Province of Lugo (where the study was carried out) due to its high growth rate (IFN, 1998). However, it could have a negative impact on the production and biodiversity of the understorey component, as Pinus radiata creates less suitable conditions (shading) for the development of understorey vegetation than Pinus pinaster or those of autochthonous broadleaves like Betula alba (Mosquera-Losada et al., 2006). Canopy cover and light interception is a key structural factor when designing and managing plantations to enhance biodiversity (Paritsis and Aizen, 2008). In managed forests, the choice of tree species is one of the fundamental acts of the forester and can have a strong impact on soil (Mosquera-Losada et al., 2006) and understorey development. Recently, Barbier et al. (2008) emphasised that studies are needed to test whether hardwoods are more favourable to understorey plant diversity than conifers at a medium- and long-term. Fertilisation as well as ploughing have also been found to have a great impact on soil $\mathrm{pH}$, understorey production and plant diversity in very acidic forest soils of the area (Mosquera-Losada et al., 2009). Fertilisation is the most useful tool to enhance pasture production when no other factors like light, temperature or humidity limits understorey growth. However, this extended practice can cause soil $\mathrm{pH}$ depletion due to the increment of cation extractions by pasture and tree and the organic matter mineralisation (Whitehead, 1995). Soil pH depletion could partially be overcome by nutrient recycling of fallen tree leaves (Moreno et al., 2007) of broadleaves compared with conifers. Fertilisation also affects diversity due to the modification of the relationship of species (presence of monocots vs. dicots), different functional ecological traits (presence of annual $v s$. perennial species) or richness. Few studies have been carried out on abandoned agricultural land that has been afforested (Schipper, 1996; Mosquera-Losada et al., 2006 and Mosquera-Losada et al., 2009) with native broadleaved or exotic conifer species taking into account soil, production and richness for a long-term. This study aims to evaluate the effect of Pinus radiata D. Don and Betula alba L. established in an abandoned agricultural land on soil $\mathrm{pH}$, understorey plant diversity, life cycle type (annuals vs. perennials) and production managed with different soil fertilisation treatments over 11 years. Ultimately, our goal was to determine the effects of extensive exotic tree species plantations as compared with autochthonous species within the context of land use change from agronomic to forest land to provide more sympathetic management to biodiversity preservation at a high tree densities.

\section{METHODS}

\section{Location}

The experiment was established in Castro Riberas de Lea (Province of Lugo, NW Spain, $43^{\circ} 01^{\prime} \mathrm{N} ; 7^{\circ} 40^{\prime} \mathrm{W}$ ). The study area is situated $439 \mathrm{~m}$ above sea level. The zone in which the study was carried out is located in the Atlantic Bioclimatic Region (EEA, 2003). The total annual rainfall and average temperature for the last 30 years were $1300 \mathrm{~mm}$ and $12 \cdot 2^{\circ} \mathrm{C}$, respectively. Generally, water deficits were registered during the months of July and August, which limited vegetal development in these months due to drought (Pearson and Ison, 1987; Mosquera and González, 1998). The experiment developed from 1995 to 2005 over a soil classified as Umbrisol (FAO, 1998), with a sandy-silty texture (61 per cent sand, 34 per cent silt and 5 per cent clay) that was previously used for agricultural purposes (cultivation of potatoes). The initial $\mathrm{pH}$ of the water (1:2.5) was close to neutrality (6.8), indicating optimum availability of nutrients for the plants (Porta Casanellas et al., 2003). The edaphic contents of organic matter and nitrogen were 8.03 per cent and 0.33 per cent, respectively, which could be considered high, but is characteristic of soils dedicated to crops in Galicia (Calvo de Anta et al., 1992). Moreover, the relation of $\mathrm{C} / \mathrm{N}$ was $14 \cdot 11$, indicating a slow mineralisation rate favouring soil organic matter accumulation.

\section{Experimental Design and Management}

The experiment was initiated in 1995 and consisted of 24 treatments and 72 experimental units arranged following a randomised block design with three replicates. Plantation has a size of around 1 ha. Only the results of six treatments out of 24 and obtained in 1995, 2000 and 2005 are described in this paper. The treatments tested two forest species Pinus radiata D. Don (from container plants) and Betula alba $\mathrm{L}$. (from bare root) established at 2500 trees ha $^{-1}$ (with a distance of $2 \times 2 \mathrm{~m}$ between trees) and three different fertilisation treatments. Each replicate or experimental unit of a total of 18 experimental unit (three replicates $\times$ six treatments) had an area of $64 \mathrm{~m}^{2}\left(8 \times 8 \mathrm{~m}^{2}\right)$, and 25 trees were planted with an arrangement of $5 \times 5$ stems, forming a perfect quadrat. In March 1995, land ploughing was carried out. Each experimental unit was sown with Dactylis glomerata $\mathrm{L}$. var. Saborto $\left(25 \mathrm{~kg} \mathrm{ha}^{-1}\right)+$ Trifolium repens L. var. Ladino $\left(4 \mathrm{~kg} \mathrm{ha}^{-1}\right)+$ Trifolium pratense $\mathrm{L}$. var. Marino $\left(1 \mathrm{~kg} \mathrm{ha}^{-1}\right)$. The fertiliser treatments applied in each experimental unit are as follows: no fertilisation (NF) for the duration of the experiment; mineral fertilisation (M) every year throughout the experiment following a standard procedure for the region: $500 \mathrm{~kg} \mathrm{ha}^{-1}$ of 8:24:16 $\left(\mathrm{N}: \mathrm{P}_{2} \mathrm{O}_{5}: \mathrm{K}_{2} \mathrm{O}\right)$ fertiliser complex in March and $40 \mathrm{~kg}$ of $\mathrm{N}$ (calcium ammonium nitrate 26 per cent $\mathrm{N}$ ) ha ${ }^{-1}$ in May; and fertilisation with dairy cattle manure sludge (D) in the first year (1995) at $154 \mathrm{~m}^{3} \mathrm{ha}^{-1}$, i.e. $160 \mathrm{~kg}$ of total $\mathrm{N}, 85.9 \mathrm{~kg}$ of 
total $\mathrm{P}_{2} \mathrm{O}_{5}$ and $23.4 \mathrm{~kg}$ of total $\mathrm{K}_{2} \mathrm{Oha}^{-1}$, with values determined based on total $\mathrm{N}$ of sludge. Also, $265 \cdot 6 \mathrm{~kg} \mathrm{ha}^{-1}$ of $\mathrm{CaO}$ and $32.8 \mathrm{~kg} \mathrm{ha}^{-1}$ of $\mathrm{MgO}$ were added together with the input of the dairy cattle manure sludge (D) treatment in 1995. Dairy cattle manure sludge was only applied in the first year of the study because this is traditionally done in the area due to difficulties related to dairy cattle manure sludge application in high density stands. Moreover, trees are more benefited from fertilisation in the first year of establishment due to the high tree plantation stress and the high tree growth rate at the start of the plantation, which therefore increases stand response to fertilisation at establishment than later. In the following 2 years (1996 and 1997), the plots to which the sludge was applied were not fertilised, but they were fertilised again from 1998 until the conclusion of the study, using the same fertilisers and doses as for M. Dairy cattle manure sludge applied in the plots had 2 per cent DM, $1.3 \mathrm{~kg} \mathrm{~m}^{-3}, \quad 0.55 \mathrm{~kg}^{\mathrm{P}} \mathrm{P}_{2} \mathrm{O}_{5} \mathrm{~m}^{-3}, \quad 0.15 \mathrm{~kg} \mathrm{~K}_{2} \mathrm{O} \mathrm{m}^{-3}, \quad 1.7 \mathrm{~kg}$ $\mathrm{CaOm}^{-3}$ and $0.21 \mathrm{MgO} \mathrm{kg} \mathrm{m}^{-3}$. These values were determined in the laboratory. Sludge DM was determined after drying $100 \mathrm{~g}$ of sludge. $\mathrm{N}, \mathrm{P}, \mathrm{Ca}, \mathrm{K}$ and $\mathrm{Mg}$ concentrations were determined after microkjeldahl digestion. $\mathrm{N}$ and $\mathrm{P}$ concentration was evaluated by colorimetry with an auto analyser (TRAACS-800 ${ }^{+}$), as per Castro et al. (1990). K, $\mathrm{Ca}$ and $\mathrm{Mg}$ concentrations were measured with a VARIAN 220FS spectrophotometer using atomic emission for $\mathrm{K}$ and absorption for $\mathrm{Ca}$ and $\mathrm{Mg}$ (VARIAN, 1989). At the end of 2001, the pine trees were low-pruned (height of $2 \mathrm{~m}$ ); at the end of 2002, formation pruning was carried out on the birch trees, with the purpose of producing good quality timber.

In this paper, we show the corresponding results at three stages in the development of the system, corresponding to the year of establishment (1995), intermediate development of the system (2000) and the final situation (2005).

\section{Soil Sampling}

During the period of study, a composite soil sample (three samples per experimental unit) was collected in each of the established experimental units, using a core to a sample depth of $25 \mathrm{~cm}$ (BOE, 1990). The samples were collected in December 1995, March 2001 and January 2006. Soil samples were carried out during the winter period, as is traditionally done in the area in order to quantify fertiliser inputs before the growing season. Once the samples were obtained, they were taken to the laboratory, air-dried and sifted using a $2 \mathrm{~mm}$ sieve, after which the $\mathrm{pH}$ of the water $(1: 2 \cdot 5)$ was determined using a pH meter (Model GLP 21 Crison).

\section{Tree Measurement}

Each year, diameter and height of Pinus radiata and Betula alba were taken from the nine central trees of each experimental unit, in order to avoid the border effect produced in the trees on the edges of the plot. Distances between replicas were $2 \mathrm{~m}$, so measured trees were at least $6 \mathrm{~m}$ away. During the first few years, measurements of diameter were made by calliper at the height of the rootcollar; later, the diameter at breast height $(1.30 \mathrm{~m})$ was measured by calliper. In order to obtain height measurements, a pole was used in 1995 and 2000, while in the last year (2005) it was necessary to use a hypsometer.

\section{Pasture Sampling}

The pasture was harvested four times each year (May, June, July and December) with the exception of the year in which the system was established (1995) and the last year (2005) in the plots established under Pinus radiata, when only two harvests (July and December) were carried out. At each harvesting in each experimental unit, the entire surface area delimited by the nine inner six trees of the plot was cleared, the fresh forage was weighed in situ and a representative subsample was taken to the laboratory. In the laboratory, the species of $100 \mathrm{~g}$ subsamples from each plot were handseparated to determine botanical composition. The different species were weighted separately to determine dry weight $\left(48 \mathrm{~h}\right.$ at $\left.60^{\circ} \mathrm{C}\right)$ to perform understorey plant diversity analyses. The species were split into annual and perennial functional groups.

\section{Diversity and Abundance}

The diversity index calculations were carried out using plant species data collected in 1995, 2000 and 2005. Once all of the species that were present in the different samples from each harvest of the established plots were identified they were summed up in a year basis and their relative percentage proportion (taking into account the four harvests of the year) was calculated.

A series of indexes were determined relative to the $\alpha$ (species richness (S) (Magurran, 2004), Shannon-Wiener index $(\mathrm{H})$ (Shannon and Weaver, 1949) and $\beta$ diversity (Jaccard Index of Similarity and the Index of Complementarities (Colwell and Coddington, 1994; Lande 1996) to compare the different stages of the experiment) from the relative species percentage proportion (Moreno, 2001) as shown in Table I.

Once the samples of pasture collected from each treatment had been separated by hand for all the species, senescent material (dead plant material) and needles and their dry-weight per cutting obtained, the annual production of each category was determined. From these data, the relative abundance of each species (expressed as part/unit) was obtained and abundance diagrams were produced, ordering the species from most to least abundance (Magurran, 2004). The aim of these diagrams was to reflect the relative evolution of the species under the two established tree covers (Pinus radiata and Betula alba), 
Table I. Beta diversity index

Jaccard $\left(I_{\mathrm{j}}\right)$ Equations

$I_{\mathrm{j}}=\mathrm{c} /(\mathrm{a}+\mathrm{b}-\mathrm{c})$ (i) Comparison between the initial (1995) and final situation (2005)

$\mathrm{a}=$ initial species number (year 1995)

$\mathrm{b}=$ final species number (year 2005)

$\mathrm{c}=$ initial and final shared species

(ii) Comparison of the similarity between plots established under the

tree cover of pine and birch trees over the three years of the study, where:

$\mathrm{a}=$ species present in systems established with pine trees

$\mathrm{b}=$ species present in systems established with birch trees

$\mathrm{c}=$ number of species present in both systems

Colwell and Coddington index of complementarities (1994) $\left(\mathrm{C}_{\mathrm{AB}}\right)$ Equations

$\mathrm{C}_{\mathrm{AB}}=\mathrm{U}_{\mathrm{AB}} / \mathrm{S}_{\mathrm{AB}}$

$\mathrm{U}_{\mathrm{AB}}=\mathrm{a}+\mathrm{b}-2 \mathrm{c}$

$\mathrm{S}_{\mathrm{AB}}=\mathrm{a}+\mathrm{b}-\mathrm{c}$

$\mathrm{S}_{\mathrm{AB}}=$ total richness of species for both plots

$\mathrm{U}_{\mathrm{AB}}=$ number of unique species in each type of plot

$\mathrm{a}=$ species present in plots of pine trees

$\mathrm{b}=$ species present in plots of birch trees

$\mathrm{c}=$ common species between plots established under the two canopies. in each of the treatments (D, M, NF) and at the three different time periods after tree planting: the beginning stage (1995), intermediate stage (2000) and final stage (2005). The evolution of the ecologic groups (annuals vs. perennials) and seeded/native species per treatment and year was also evaluated.

\section{Statistical Analysis}

The variables studied were $\mathrm{pH}$, diameter and height of the trees, biomass, and $\alpha$ and $\beta$ plant diversity. For the first five variables, the results obtained were analysed with Repeated Measures ANOVA, using Mauchly's Criterion to test sphericity. If sphericity assumption was met then univariate approach output was used, otherwise multivaritae output (Wilks' Lambda test was taken into account). The LSD (Least Significant Difference) test was used for subsequent pairwise comparisons after a normalisation test $(\alpha=0.05)$ only when factors were significant in the ANOVA analyses. Correspondence analyses (CA) with all the treatment and replicas were carried out to determine how the number of native/spontaneous species and how annual/perennial in each year interacted with the different tree systems (exclusive pine species, exclusive birch species and species shared by both tree systems). The statistical software package SAS (2001) was used for all analyses with the exception of CA which was performed with SPSS (v 15.0).

\section{RESULTS}

\section{$p H$}

In the samplings made in the three stages of the study, progressive acidification was produced irrespective of the type of tree established $[F(2,28)=36.02 ; p=0.001]$
(Figure 1). A significant interaction year* fertilisation $[F(4,28)=2 \cdot 81 ; p=0 \cdot 04]$ was found in soil $\mathrm{pH}$. Inorganic fertilisers $(\mathrm{M})$ caused a smaller reduction in water $\mathrm{pH}$ than $\mathrm{D}$ and NF treatments (Figure 1), being this effect more important at the start than at the end of the experiment. Moreover, the effect was also significant at the end of the study and did not depend on tree cover $[F(2,28)=2.45$; $p=0 \cdot 10]$. The initial soil water $\mathrm{pH}$ was $6 \cdot 8$ (Figure 1), reaching values of 5.40, 6.10 and 5.67 at the end of the experiment (2005) under pine trees, and values of 5.67, 6·10 and 5.90 under birch trees for organic fertilisers (D), mineral fertilisers (M) and no-fertilisers (NF), respectively.

\section{Tree Growth}

Mauchly's sphericity tests were significant when the height and diameter of trees were examined; therefore, multivariate approach was selected for testing within subject factors. Tree diameter $[F(2,94)=233.49 ; p=0.001]$ and height $[F(2,90)=510 \cdot 77 ; p=0 \cdot 001]$ growth changes with the year of sampling. Significant interactions of year* fertilisation were detected in the multivariate test for tree diameter $[F(4$, $188)=2.52 ; \quad p=0.04]$ and height $[F(4,180)=4.47$; $p=0.001]$. Change in mean tree height $[F(2,90)=51.74$; $p=0.001]$ and diameter $[F(2,94)=64.40 ; p=0.001]$ across tree levels depended upon year. The height and diameter growth of Pinus radiata 11 years after establishment was greater than that of Betula alba (Figure 2). The results show that from the beginning of the experiment, the application of mineral fertiliser (M) reduces the height growth of pine trees compared with no fertilisation treatment by 22 per cent at the end of the study; the same effect was seen in birch trees in 2005 (33 and 42 per cent for height and diameter, respectively). However, birch response 


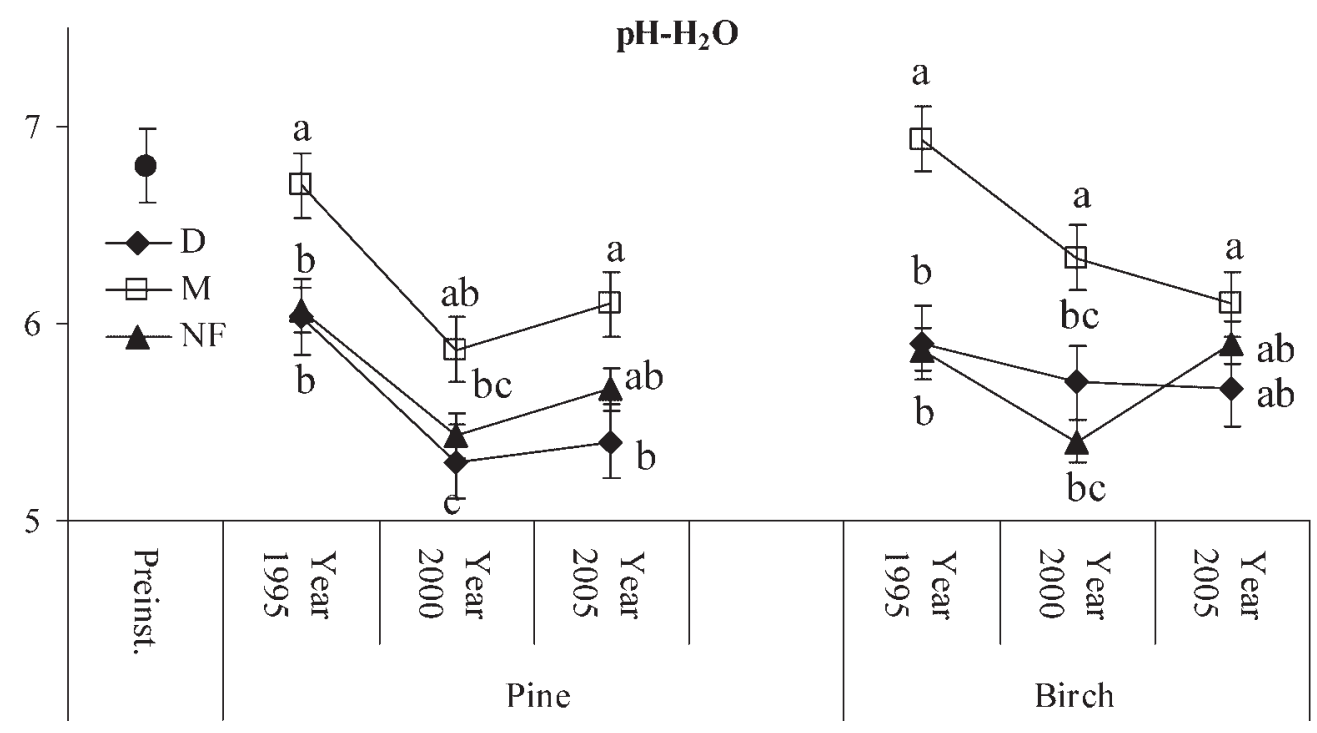

Figure 1. pH at the time of system establishment and in the years 1995, 2000 and 2005 under Pinus radiata D. Don (pine) and Betula alba L. (birch), where: Preinst. $=$ pre-installation, $\mathrm{D}=$ fertilised with sludge, $\mathrm{M}=$ mineral fertiliser and $\mathrm{NF}=$ not fertilised. Different letters indicate significant differences between the six treatments for each year.

to fertiliser treatments was enhanced by mineral fertilisation in 2000 .

\section{Annual Aerial Biomass}

Year factor had a significant negative effect on annual pasture production $[F(2,28)=39 \cdot 18 ; p=0 \cdot 001]$. However, senescent $[F(2,13)=15 \cdot 29 ; p=0 \cdot 001]$ and needle $[F(2$, $13)=38.79 ; p=0.001]$ percentages were positively influenced by year. The interaction year* tree was also significant for annual pasture production $[F(2,18)=14 \cdot 69 ; p=0 \cdot 001]$ and needle percentage $[F(2,13)=38 \cdot 79 ; p=0 \cdot 001]$. Apart from this, annual pasture production was positively and significantly affected by fertiliser effect $[F(2,14)=21.91$; $p=0 \cdot 001]$.

The annual pasture production of the different treatments varied between $3.45-5.48,1.71-3.33$ and $0.11-$ $0.33 \mathrm{tDM} \mathrm{ha}^{-1}$ in the plots established under pine trees in the years 1995, 2000 and 2005, respectively (Figure 3). In the case of the plots established under birch trees, the ranges were $3 \cdot 88-5 \cdot 32, \quad 1.89-5 \cdot 20$ and $3 \cdot 22-3.86 \mathrm{t} \mathrm{DM} \mathrm{ha}^{-1}$, respectively. Tree effect on pasture production was more important at the end of the experiment than at the start, as pine canopy significantly reduced pasture production in 2005. However, pasture production was positively affected by mineral and dairy cattle manure sludge fertilisation in 1995 in pine and birch system, and below birch in 2000 .

Senescent material biomass increased from 1995 (below $0 \cdot 12 \mathrm{tDM} \mathrm{ha}^{-1}$ under both tree species) to 2000 (below 0.72 and $0.33 \mathrm{tDM} \mathrm{ha}^{-1}$ under pine and birch, respectively) and 2005 (above 0.84 and $0.62 \mathrm{tDM} \mathrm{ha}^{-1}$ under pine and birch respectively); this increment was significantly higher under pine in NF and D treatments than under birch due to faster development of the pine canopy (Figure 3). The contribution of the needles to the annual aerial biomass in the pine tree plots was significantly greater during 2005 than in previous years.

\section{Diversity Analysis}

In the 3 years studied, a total of 57 species (sp) were recorded, 48 dicotyledonae and nine monocotyledonae. The families with the greatest species richness were Compositae (12 sp), Gramineae (nine sp), Leguminoseae (eight sp), Caryophillaceae (six sp) and Polygonaceae (five sp) (Table II). In regard to their ecologic groups, 24 species were annuals, and 26 were perennials; the rest (seven) were biennials. In 1995, the percentage of annual species was approximately 60 per cent in the plots established under the canopy of pine trees and 55 per cent under the canopy of birch trees. In contrast, by 2005, the presence of annual species was zero under the canopy of pine trees and varied between 27 and 53 per cent under the canopy of the birch trees (Figure 4).

Year $[F(2,28)=276 ; p=0.001]$ in a negative way and year ${ }^{*}$ tree interaction $[F(2,28)=18 \cdot 11 ; p=0.001]$ significantly affected Species Richness (S) and Shanon index $[F(2$, $28)=72 \cdot 72 ; p=0.001$ and $F(2,28)=30.95 ; p=0.001$, respectively], so tree canopy effect on plant diversity depended on the age of the stand. Fertiliser type effect was also significant for $\mathrm{S}[F(2,14)=15 \cdot 60 ; p=0.001]$ and $\mathrm{H}$ $[F(2,14)=3.55 ; p=0 \cdot 05]$, being usually both higher in no fertiliser than in fertilised treatments. $\mathrm{S}$ in the plots under conifers varied between $20-28,15-18$ and 2 species in 1995 , 
(m)

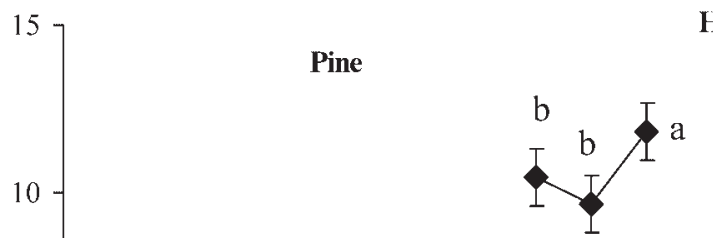

Height

Birch
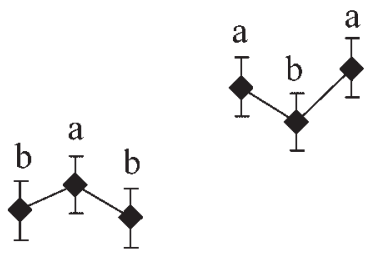

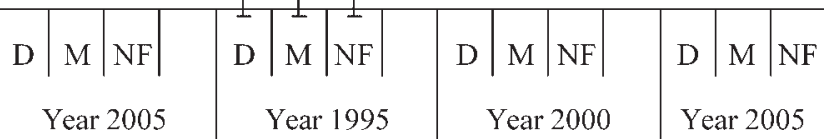

Treatments

(cm)

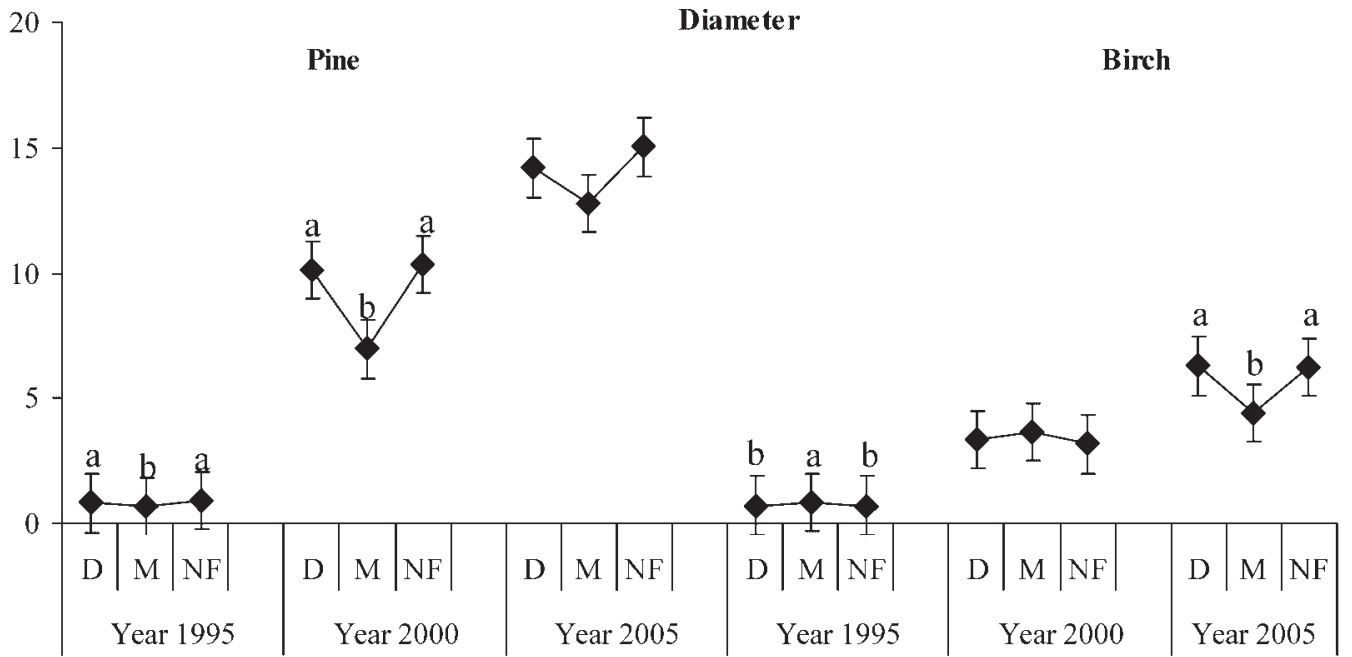

Treatments

Figure 2. Height and diameter of Pinus radiata D. Don (pine) and Betula alba L. (birch) for the years 1995, 2000 and 2005. Note: D = fertilised with sludge, $\mathrm{M}=$ mineral fertiliser and $\mathrm{NF}=$ not fertilised. Different letters indicate significant differences between treatments within each tree species.

2000 and 2005, respectively. In the systems established with birch trees, the $\mathrm{S}$ was steadier over time, varying between 18-23, 15-20 and 15-19 species for the same years, respectively (Figure 5). Dactylis glomerata was the most abundant species in almost all of the treatments throughout the 11 years of study, with the exception of Pinus radiata when Prunella vulgaris L. codominated with Dactylis glomerata. Dactylis glomerata presence was close to or above 50 per cent on many occasions with the exception of the no-fertiliser plots (NF) developed under the canopy of birch trees in 1995 and 2000 (Figure 5).

The Shannon diversity index $(\mathrm{H})$ varied between $1 \cdot 16$ $1.94,1.34-1.79$ and $0.04-1.63$ for the years 1995,2000 and 2005 , respectively. The effect of tree on $\mathrm{H}$ depended on the age of the stand. During the first year, a significant decrease in plant diversity was observed in plots established under the canopy of birch trees and those fertilised with M compared with pine tree treatment (Figure 6). This floristic diversity reduction was also noticed during the last year, when $\mathrm{H}$ was significantly reduced in the plots planted with conifers.

The floristic composition of the two established systems showed important differences over the 11 years of the study (Table III). The variation in floristic composition was more noticeable in the case of pasture established under pine trees than under birch trees. Under the canopy of pine trees, only 3 per cent of the species were shared between the initial situation (agricultural land) and the final situation (forest land), while in the case of systems established with birch 


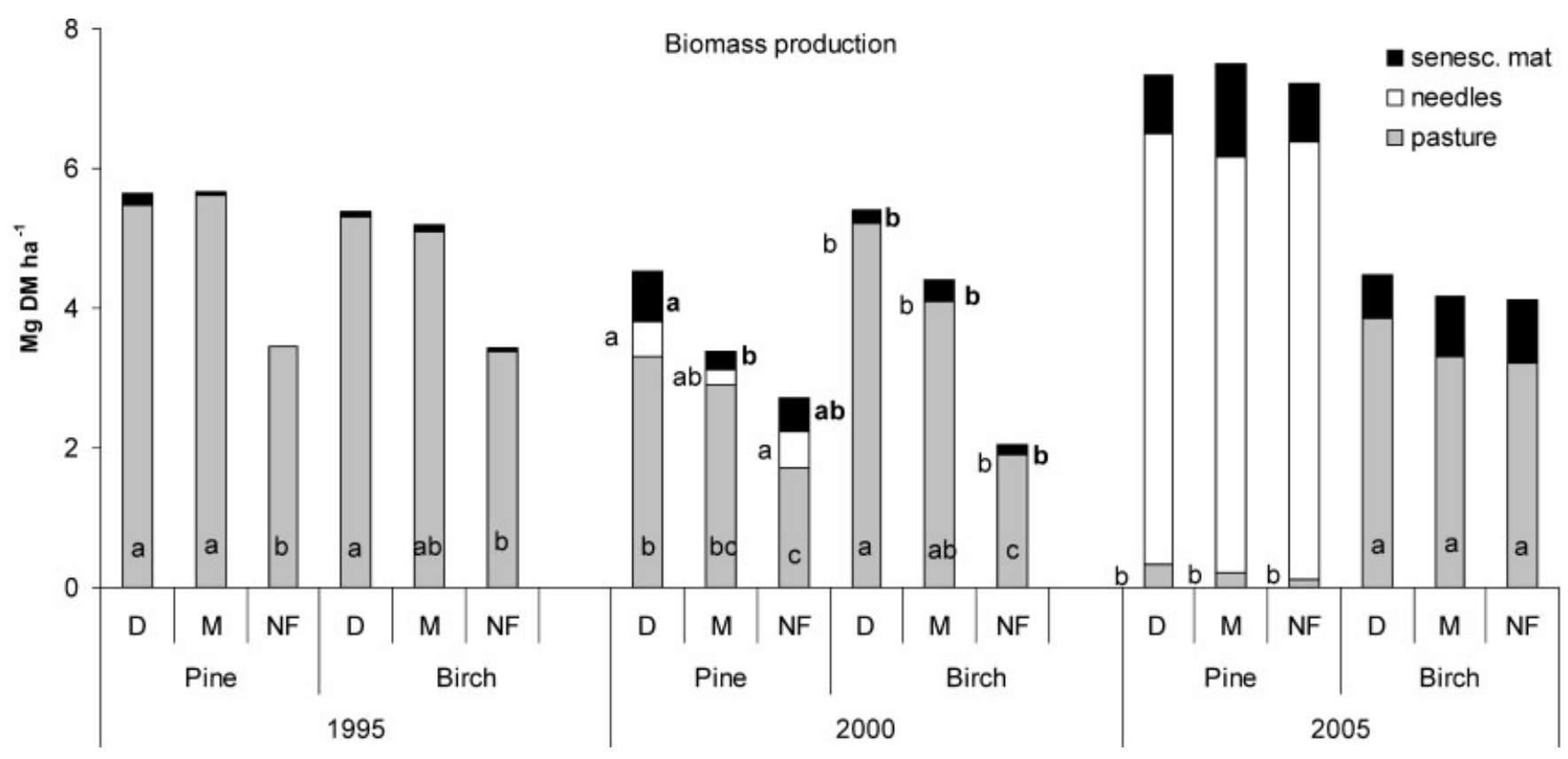

Figure 3. Variation in the biomass components: senescent material (senesc. mat.), needles and pasture production (pasture) under pine and birch, and fertiliser with dairy cattle manure sludge (D), mineral fertiliser (M) and not fertilised (NF). Different letters indicate significant differences between the six treatments per each biomass component in the same year.

trees, this percentage rose to 30 per cent (Table II). In the first two periods of study (1995 and 2000), the floristic composition of the two systems was very similar, sharing 65 and 71 per cent of their species (Table III), respectively; the greatest differentiation in the species was observed in the final period $\left(I_{\mathrm{j}}=0 \cdot 11\right)$. In the first 2 years of study (1995 and 2000), approximately 30 per cent of the species were different between the two types of tree canopies (Table III). In the final year, the degree of dissimilarity between the two systems increased substantially ( 89 per cent).

The correspondence analysis graphical output is shown in Figure 7. The percentage of variance explained of dimension 1 in the graphs native/spontaneous or annual/perennials vs. tree system was very high ( 89 and 83 per cent, respectively). It can be seen that the number of native and seeded species as well as annual and perennials were mostly related with birch in the year 2005 compared with the other years and pine or shared species of pine and birch.

\section{DISCUSSION}

Most of the variables evaluated in this study were differently affected by treatments depending on the evaluated year. Those treatments with higher tree growth rate and pasture production (D and NF) significantly reduced soil $\mathrm{pH}$ due to higher cation soil extraction caused by the better development of these components. Cation extraction increment is, among other mechanisms like leaching and mineralisation, one of the main causes of soil acidification (Whitehead, 1995). This effect was especially relevant (and appeared earlier) under the faster-growing species (pine) compared to the native slower-growing species (birch). Under birch, the effect of fertilisation on soil $\mathrm{pH}$ decreased over time; this could be explained by fallen birch leaves, which were easily incorporated into the soil. Birch leaves have a high proportion of calcium (Palviainen et al., 2004), which reduces the negative impact of soil calcium leaching and extraction caused by pasture and trees (Rigueiro-Rodríguez et al., 2009), thus allowing for better nutrient recycling than pine trees, whose needles do not incorporate into the soil easily.

As the tree cover of both established systems developed, a negative relationship was found between pasture production and tree canopy development. This negative relationship was greater in the case of the systems established under the Pinus radiata canopy as found by Mosquera-Losada et al. (2006), resulting in reduced plant diversity under pine, probably due to its faster growth, which caused earlier canopy closure (Ferris et al., 2000). Pinus radiata negative effect on pasture production and diversity is probably more important than that created by the native coniferous Pinus pinaster species, due to the faster growth rate and the denser aerial structure type of the Pinus radiata exotic species, which limits the amount of light reaching the understorey (Rozados et al., 2007). Conifer tree plantations also cause important understorey changes compared with native 
Table II. List of species found during the period of study in plots established with pine and birch trees

\begin{tabular}{|c|c|c|c|c|c|c|c|c|c|c|}
\hline & & & & & & Pine & & & Birch & \\
\hline Class. & Family & Specie & Cod. & Cycle & 1995 & 2000 & 2005 & 1995 & 2000 & 2005 \\
\hline \multirow{22}{*}{ Di } & Boraginaceae & Lithodora prosiata Loisel & $\mathrm{Li}$ & $\mathrm{P}$ & & & & & & $\mathrm{x}^{\mathrm{NF}}$ \\
\hline & \multirow{2}{*}{ Cruciferae } & Lepidium heterophyllum Bentham & Lep & $P$ & & & & & $x^{M}$ & \\
\hline & & Raphanus raphanistnum L. & $\mathbf{R p}_{\mathbf{p}}$ & $\mathrm{A}$ & $x^{3}$ & & & $\mathbf{x}^{\mathrm{DM}}$ & & $x$ \\
\hline & \multirow{6}{*}{ Caryophyllaceae } & Cerastium glomeratum Thuill & Cer & $\mathrm{A}$ & $\mathbf{x}$ & $x$ & & $x^{3}$ & $x^{0}$ & $\mathrm{x}^{3}$ \\
\hline & & Illecebnom verticillatum $\mathrm{L}$. & II & $\mathrm{A}$ & $x$ & & & & & \\
\hline & & Scleranthus annuus L. & Sc & $\mathrm{A}$ & & & & $x^{\mathrm{NF}}$ & & \\
\hline & & Silene gallica L. & $\mathrm{Si}$ & $\mathrm{A}$ & $x^{3}$ & & & $x^{3}$ & & \\
\hline & & Spergula arvensis $\mathrm{L}$. & $\mathrm{Sp}$ & $\mathrm{A}$ & $x^{3}$ & & & $x^{3}$ & & \\
\hline & & Stellaria media L (Vill) & St & $\mathrm{A}$ & $\mathrm{x}^{\prime \prime}$ & & & & & \\
\hline & Chenopodiaceae & Chenopodium album L & $\mathrm{Ch}$ & $\mathrm{A}$ & $\mathrm{x}^{\mathrm{DN}}$ & $x$ & & $x^{3}$ & $\mathbf{x}$ & $\mathbf{x}$ \\
\hline & \multirow{12}{*}{ Compositae } & Anthemis anvensis $\mathrm{L}$. & Aa & A & $\mathrm{x}^{\mathrm{DM}}$ & & & $x$ & & \\
\hline & & Achillea millefolium $\mathrm{L}$. & Ach & $\mathrm{P}$ & & $x^{\mathrm{Vin}}$ & & & & \\
\hline & & Chamaemelum mixtum L. & Cham & $\mathrm{A}$ & & & & & & $x^{\prime \prime}$ \\
\hline & & Coleostephus myconis (L.) Rchb.f & Col & $\mathrm{A}$ & $x^{\text {NF }}$ & & & & & \\
\hline & & Crepis capillaris (L.) Wallr & $\mathrm{Cr}$ & $\mathrm{A}$ & $\mathbf{x}$ & & & $x^{3}$ & & \\
\hline & & Hieracium pilosella L. & $\mathrm{H}$ & $\mathrm{P}$ & & & & & & $\mathbf{x}$ \\
\hline & & Leontodon saxatilis Lam & Le & $\mathrm{P}$ & & & & & & $x^{N F}$ \\
\hline & & Chamomilla recutita $\mathrm{L}$. & Mat & A-B & & $x^{M}$ & & & $x^{N F}$ & $x^{3}$ \\
\hline & & Sonchus asper L. (Hill) & Sas & $\mathrm{A}$ & $x^{N F}$ & & & & & \\
\hline & & Senecio jacobaea $\mathrm{L}$. & Se & B-P & & $\mathrm{x}^{3}$ & $x^{M}$ & & $\mathrm{x}^{3}$ & $x^{3}$ \\
\hline & & Sonchus ole raceus L. & So & $\mathrm{A}$ & & $x^{3}$ & & & $x^{3}$ & $\mathrm{x}^{\mathrm{DM}}$ \\
\hline & & Taraxacum officinale Weber & $\mathrm{Ta}$ & $\mathrm{P}$ & & $x^{3}$ & & & $x^{3}$ & $x^{3}$ \\
\hline \multirow{9}{*}{ Mon } & \multirow{9}{*}{ Poaceae } & Agrostis capillaris L. & Aca & $\mathrm{p}$ & $x^{3}$ & $x^{3}$ & & $x^{3}$ & $x^{3}$ & $x^{3}$ \\
\hline & & Dactylis glomerata L. & $\mathrm{Dg}$ & $\mathrm{P}$ & $x^{3}$ & $x^{3}$ & $x^{3}$ & $x^{3}$ & $x^{3}$ & $x^{3}$ \\
\hline & & Elymus repens L. & El & $\mathrm{p}$ & & & $x^{N F}$ & & & \\
\hline & & Holcus lanatus L. & $\mathrm{HI}$ & $\mathrm{p}$ & $x^{3}$ & $x^{3}$ & & $x^{3}$ & $x^{3}$ & $x^{3}$ \\
\hline & & Holcus mollis L. & $\mathrm{Hm}$ & $\mathrm{P}$ & $x^{3}$ & & & $x^{3}$ & & $x^{0}$ \\
\hline & & Lolium multiflonum Lam & L.m & $\mathrm{A}$ & & $\mathrm{x}^{0}$ & & & $x$ & \\
\hline & & Lolium perenne $\mathrm{L}$. & $L_{p}$ & $\mathrm{p}$ & $x^{3}$ & $x^{3}$ & & $x^{3}$ & $x^{3}$ & $x^{\text {OM }}$ \\
\hline & & Poa pratensis $\mathrm{L}$. & Poa & $\mathrm{P}$ & & & & & $x$ & \\
\hline & & Poa trivialis $\mathrm{L}$. & $\mathrm{Pt}$ & $\mathrm{P}$ & $x^{\text {NF }}$ & & & $x^{N F}$ & & \\
\hline \multirow{27}{*}{ Di } & \multirow{3}{*}{ Geraniaceae } & Erodium maschatum (L.) L Hér. & Er & A-B & & & & & & $x^{\prime \prime}$ \\
\hline & & Geranium dissectum $\mathrm{L}$. & Gd & A-B & $x^{N F}$ & & & $x^{M}$ & & \\
\hline & & Geranium rotundifolium L. & Gr & $\mathrm{A}$ & $x^{3}$ & & & & $x^{N F}$ & \\
\hline & \multirow{2}{*}{ Labiatae } & Mentha suaveolens Ehrh & Me & $\mathrm{P}$ & & & & & & $x^{D}$ \\
\hline & & Prunella vulgaris L. & $\mathrm{P}_{\mathrm{T}}$ & $\mathrm{P}$ & & & $x^{0}$ & & & $x^{N F}$ \\
\hline & \multirow{8}{*}{ Leguminosae } & Lupinus luteus L. & Lpl & $\mathrm{A}$ & $\mathbf{x}$ & & & $x^{N F}$ & & \\
\hline & & Lotus comiculatus $\mathrm{L}$. & Lt & $\mathrm{P}$ & & & & & & $x^{\prime \prime \prime}$ \\
\hline & & Medicago sativa $\mathrm{L}$. & Ms & $\mathrm{P}$ & & $x^{\mathrm{NF}}$ & & $\mathbf{x}$ & & \\
\hline & & Omithopus compressus L & Ot & A & $x$ & & & $\mathbf{x}$ & & \\
\hline & & Trifolium campestre Schreber & Te & $\mathrm{A}$ & $x^{3}$ & & & $x^{3}$ & $x^{\text {NFF }}$ & $x^{11}$ \\
\hline & & Trifolium pratense $\mathrm{L}$. & $T_{p}$ & $\mathrm{P}$ & & $x^{\mathrm{NF}}$ & & $x^{N F}$ & $x$ & \\
\hline & & Trifolium repens $\mathrm{L}$. & Tt & $\mathrm{P}$ & $x^{3}$ & $x^{3}$ & & $x^{3}$ & $x$ & $x^{N F}$ \\
\hline & & Vicia sativa $\mathrm{L}$. & $\mathrm{v}_{\mathrm{i}}$ & A-B & $x^{\text {NF }}$ & & & & & \\
\hline & Linaceae & Linum bienne Miller & Ln & A.B & $x^{0}$ & & & & & \\
\hline & Plantaginaceae & Plantago lanceolata $\mathrm{L}$. & PI & $\mathrm{p}$ & $x$ & $x^{3}$ & & $\mathbf{x}$ & $x^{3}$ & $x^{0}$ \\
\hline & \multirow{5}{*}{ Polygonaceae } & Polygonum aviculare L. & Pya & A & $x^{\mathrm{NF}}$ & & & & & \\
\hline & & Polygonum hydropiper L. & Pyh & A & $x^{3}$ & & & $x^{3}$ & & \\
\hline & & Rumex acetosa L. & Ra & $\mathrm{P}$ & & & & & $x^{3}$ & \\
\hline & & Rumex acetosella $\mathrm{L}$. & RII & $\mathrm{P}$ & $x^{3}$ & $x$ & & $\mathrm{x}^{\mathrm{DM}}$ & $x^{0}$ & $x^{3}$ \\
\hline & & Rumex obtusifolius L. & Ro & p & $\mathrm{x}$ & $x^{\text {DII }}$ & & $x^{M}$ & $x$ & \\
\hline & Portulacaceae & Montia fontana $\mathrm{L}$ & Mon & $\mathrm{P}$ & & & & $x^{\mathrm{NF}}$ & & \\
\hline & Ranunculaceae & Ranunculus repens L. & $\mathrm{Rn}$ & $\mathrm{P}$ & & & & & & $x^{\prime \prime}$ \\
\hline & Solanaceae & Solanum nignom L. & Sn & $\mathrm{A}$ & $x^{3}$ & & & $\mathbf{x}$ & & \\
\hline & \multirow{2}{*}{ Scrophulariaceae } & Rhinanthus minor L. & Ri & $\mathrm{A}$ & & & & $x^{N F}$ & & \\
\hline & & Veronica agrestis L. & $\mathrm{V}_{\mathrm{a}}$ & A & & & & & & $x^{\prime \prime}$ \\
\hline & \multirow[t]{2}{*}{ Umbelliferae } & Daucus carota $\mathrm{L}$. & Dau & $\mathrm{B}$ & $x^{3}$ & $x^{3}$ & & $x^{M}$ & $x^{3}$ & $x^{3}$ \\
\hline & & Total sp & & & 32 & 19 & 4 & 29 & 22 & 27 \\
\hline
\end{tabular}

Where: Class: $\mathrm{Di}=$ dicotyledonae, $\mathrm{Mon}=$ monocotyledonae; Cod: species code; Cycle: $\mathrm{P}=$ perennial species, $\mathrm{A}=$ annual species, $\mathrm{B}=$ biannual species; $\mathrm{X}^{\mathrm{DM}}$ : species associated only with fertiliser treatments; $\mathrm{X}^{\mathrm{NF}}$ : species associated only with plots that were not fertilised (NF), $\mathrm{X}^{3}$ : species that appear in both the fertilised and non-fertilised plots, $\mathrm{X}^{\mathrm{D}}$ : species that are only associated with organic fertiliser, and $\mathrm{X}^{\mathrm{M}}$ : species that are only associated with inorganic fertiliser. 


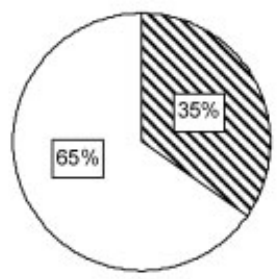

SR:23
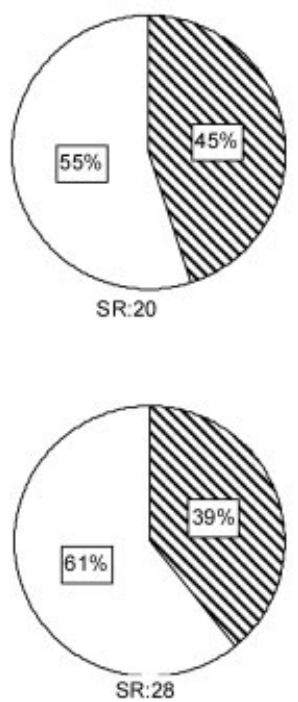

1995

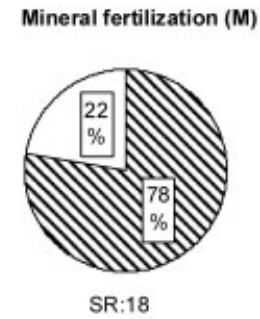

No Fertilization (NF)

Pinus radiata D. Don

dairy cattle manure sludge (D)

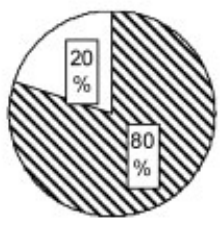

SR:15

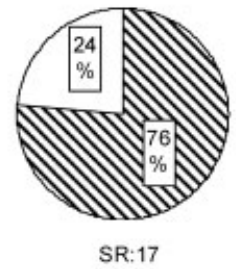

2000

2005
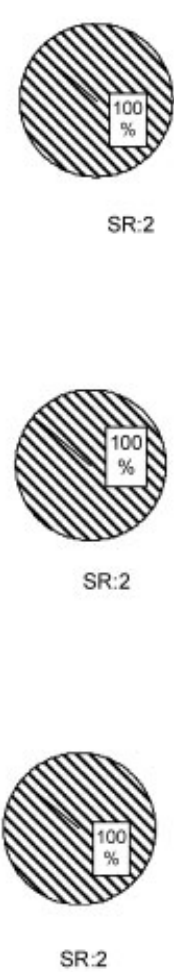

SR:2
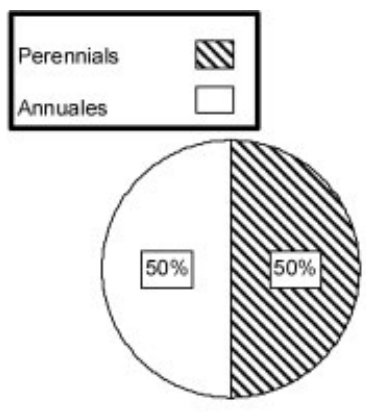

SR:18

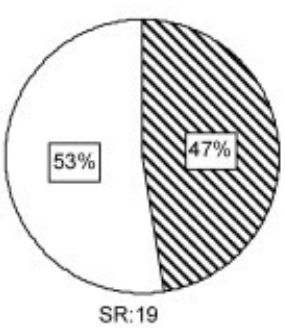

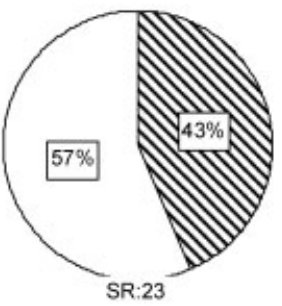

1995
Betula alba L.

dairy cattle manure sludge(D)

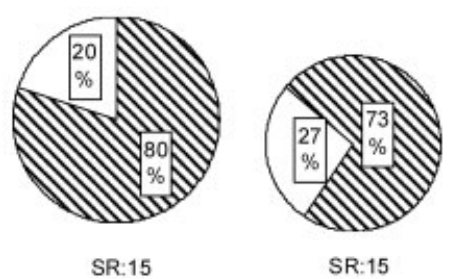

Mineral fertilization (M)
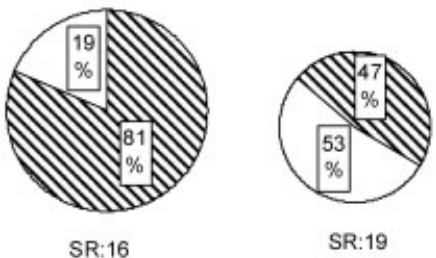

No Fertilization (NF)
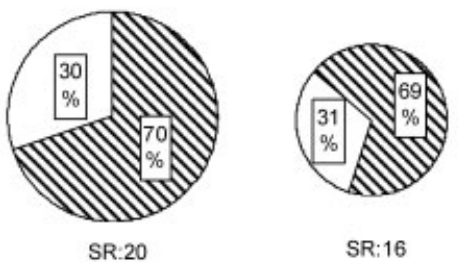

2000

Figure 4. Variation in the percentage of annual and perennial species in the years 1995, 2000 and 2005 of the study in the systems established under the cover of pine and birch trees and for each application of fertiliser where SR $=$ species richness.

broadleaved species due to their different canopy type, light interception and structure (Brockerhoff et al., 2001).

There was important variation in the understorey vegetation of the two established systems (conifers and leafy trees) during the 11-year study period, as can be seen with the types (annuals/perennials) and richness (number of species) of species. The factors that contributed to these differences in plant diversity are complex, but can be placed into two main groups: (1) anthropogenic factors (disturbances such as ground preparation, pasture mowing, thinning regime, clearing and fertiliser application) and (2) factors related to the overstorey (growth, canopy development, stand structure, etc.). Anthropogenic factors play an important role in structuring plant communities (Grime, 1982; Terradas, 2001; Augusto et al., 2002). In this study, the first disturbance was related to soil preparation in 1995 (ploughing and grading). This intervention favours the germination of annual species, mainly characterised by heliophytes and invaders such as Anthemis arvensis L.,
Crepis capillaris (L.) Wallr, Lupinus luteus L., Ornithopus compressus L., Polygonum hydropiper L., Solanum nigrum L., Spergula arvensis L. and Silene gallica L. (all of which were present in the two established systems), Coleostephus myconis (L.) Rchb. F., Sonchus asper L. (Hill), Illecebrum verticillatum L., Polygonum aviculare L., Stellaria media L. (Vill) (exclusively present in the plots replanted with pine trees), Rhinanthus minor L. and Scleranthus annuus L. (exclusively present in the plots afforested with birch trees) (Table I). Similar findings in areas with soil disturbance have been obtained by Dyrness (1973), who found that resurgence of residual herbaceous species can follow an initial period of dominance by invading species, or by Wallace et al. (1992) or Wallace and Good (1995) in conifer plantations, where ground flora communities were dominated by lightdemanding species in the first few years. In the following years, the presence of annual species began to decrease in the understorey vegetation, especially in the systems established under the pine tree canopies (100 per cent of 
A. RIGUEIRO-RODRÍGUEZ ET AL.
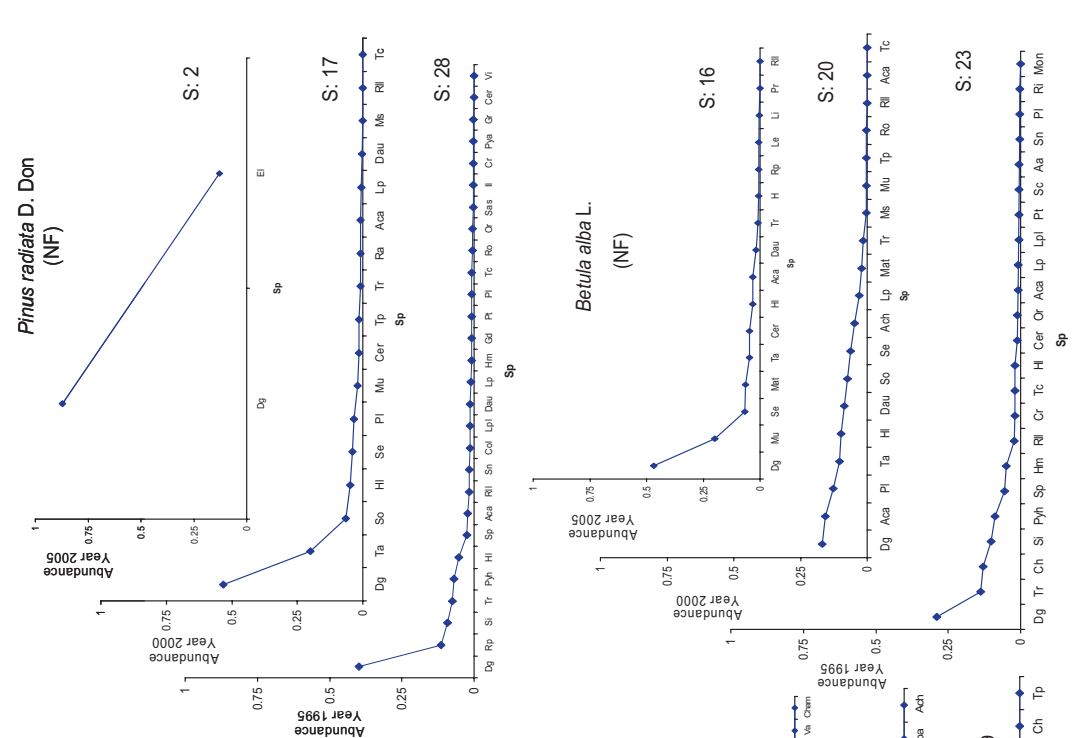

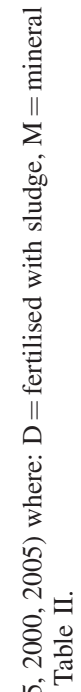
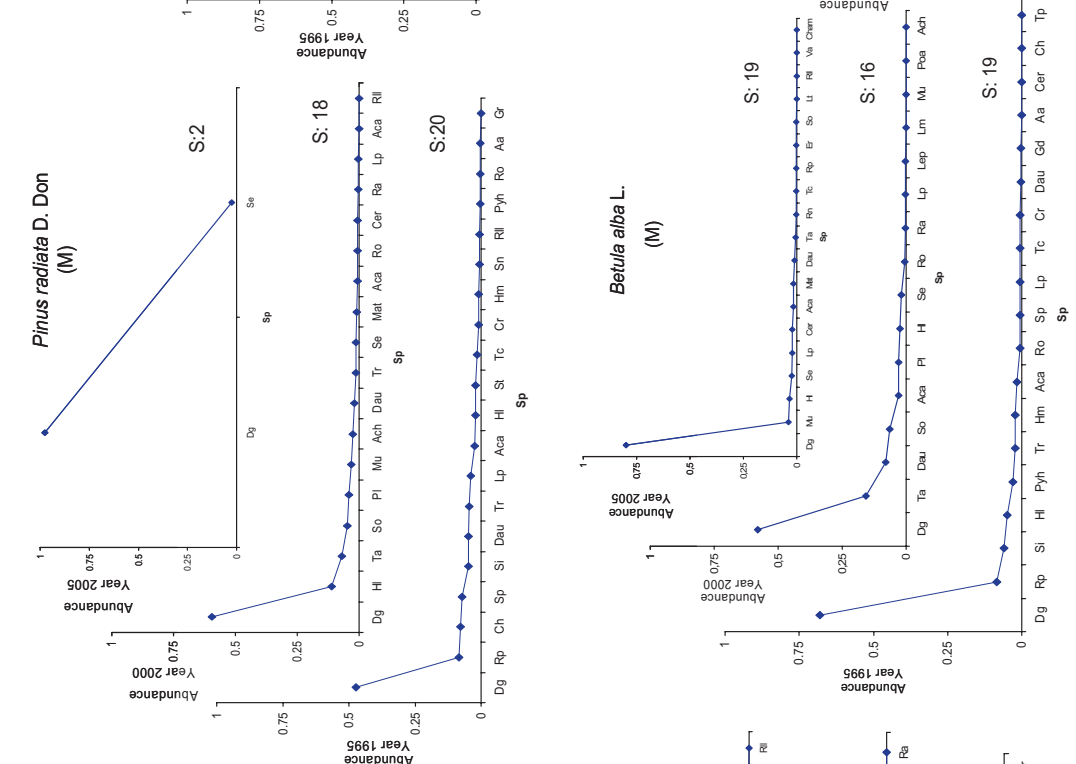

ส.

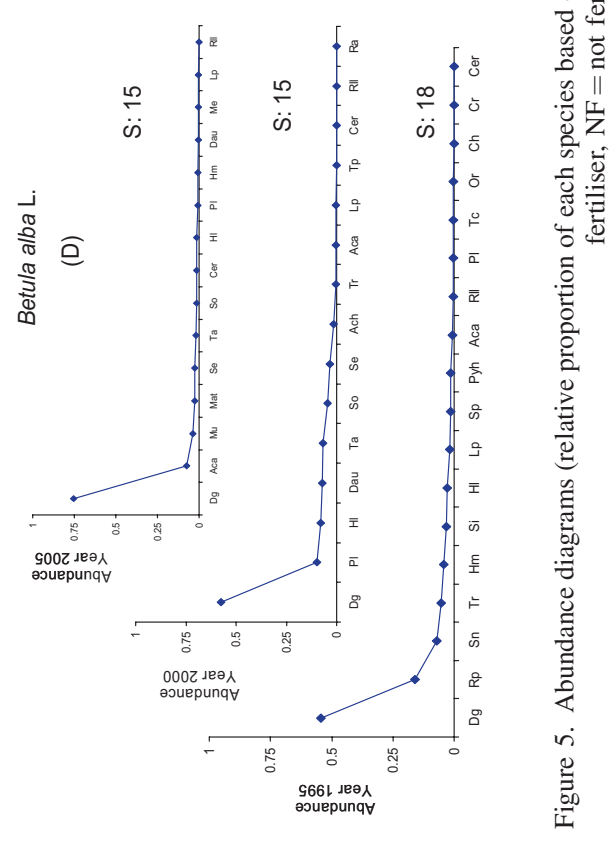

Copyright (C) 2011 John Wiley \& Sons, Ltd.

LAND DEGRADATION \& DEVELOPMENT, 23: 227-241 (2012) 


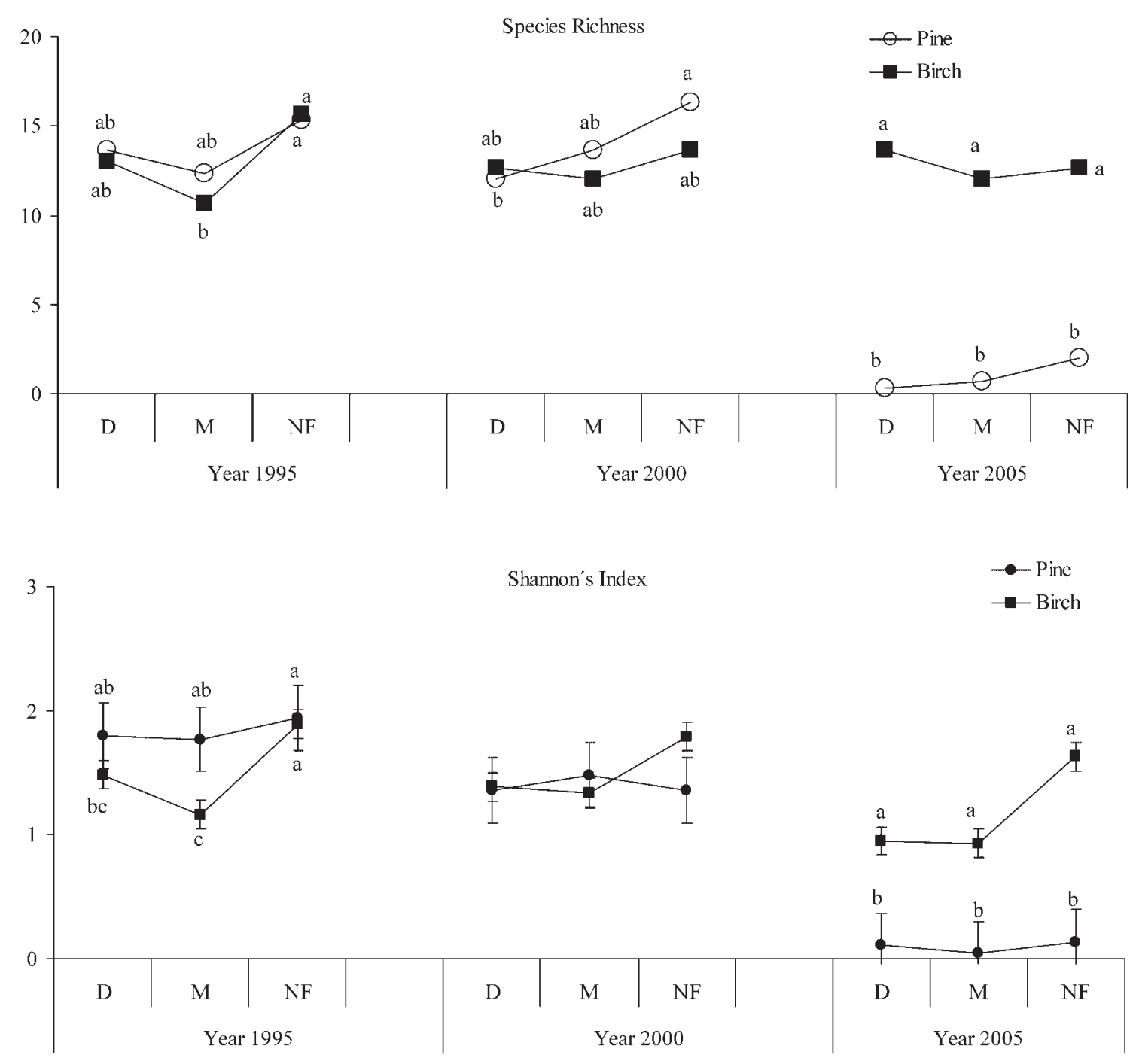

Figure 6. Species richness and Shannon-Wiener indexes determined for each of the fertiliser treatments applied under the two types of trees established and over the 3 years of study where: D: fertilised with dairy cattle manure sludge, M: mineral fertiliser and NF: not fertilised. Different letters indicate significant differences between treatments in the same year.

Table III. Jaccard $\left(I_{\mathrm{j}}\right)$ index determination where: (i) comparison between initial situation (1995) and final situation (2005) of the established plots, and (ii) determination for each year of the study. Index of Complementarity $\left(\mathrm{C}_{\mathrm{AB}}\right)$ between the plots established under pine trees and birch trees in the three years of study

Beta diversity index

Jaccard index

Index of complementarity $\left(\mathrm{C}_{\mathrm{AB}}\right)$

(i) Comparison between initial and final situation

\begin{tabular}{|c|c|c|c|c|c|c|c|c|}
\hline Species & $a_{1995}$ & $\mathrm{~b}_{2005}$ & $\mathrm{C}$ & $\mathrm{I}_{\mathrm{j}}$ & & Year 1995 & Year 2000 & Year 2005 \\
\hline Pine & 32 & 4 & 1 & 0.03 & a & 32 & 19 & 4 \\
\hline Birch & 29 & 27 & 13 & $0 \cdot 30$ & $\mathrm{~b}$ & 29 & 22 & 27 \\
\hline \multicolumn{5}{|c|}{ (ii) Determined for each year of the study } & $\mathrm{c}$ & 24 & 17 & 3 \\
\hline Year & $a_{\text {pine }}$ & $b_{\text {birch }}$ & $\mathrm{c}_{\text {pine-birch }}$ & $\mathrm{Ij}$ & $\mathrm{S}_{\mathrm{AB}}$ & 37 & 24 & 28 \\
\hline 1995 & 32 & 29 & 24 & 0.65 & $\mathrm{U}_{\mathrm{AB}}$ & 13 & 7 & 25 \\
\hline 2000 & 19 & 22 & 17 & 0.71 & $\mathrm{C}_{\mathrm{AB}}$ & $0 \cdot 35$ & $0 \cdot 29$ & $0 \cdot 89$ \\
\hline 2005 & 4 & 27 & 3 & $0 \cdot 11$ & & & & \\
\hline
\end{tabular}


Native vs. Seeded species

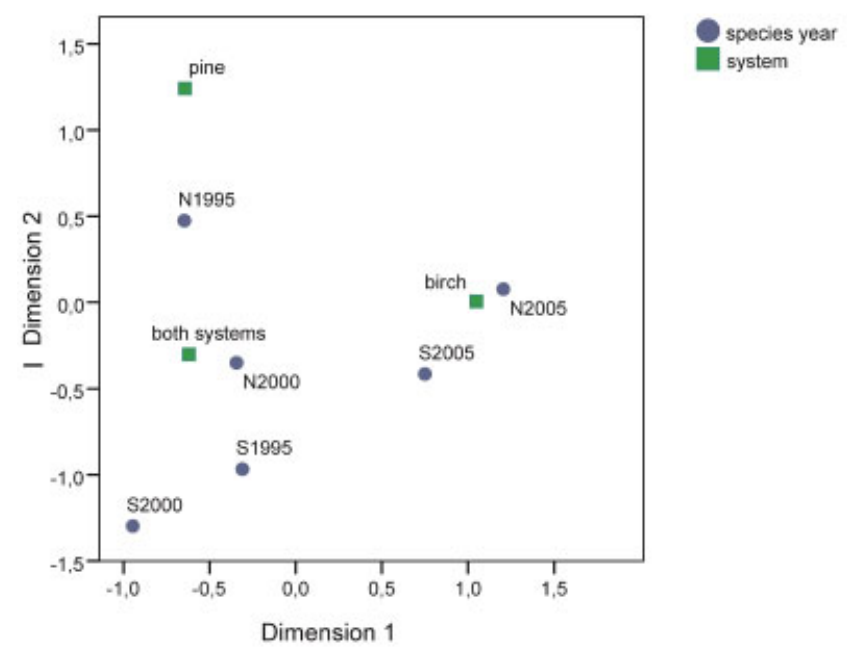

Annual vs. Perennial species

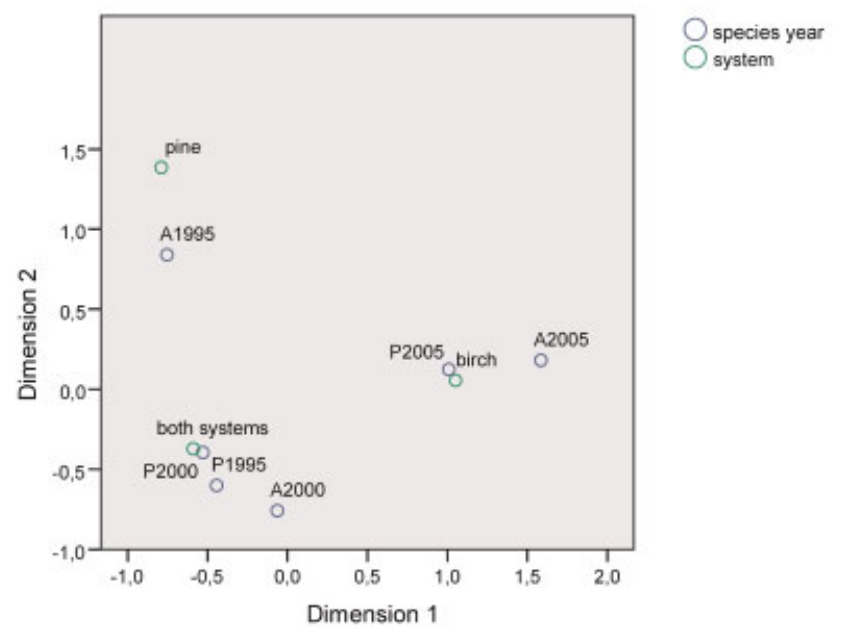

Figure 7. Correspondence analysis graph of categories related to the number of native $(\mathrm{N})$ and seeded $(\mathrm{S})$ species (above) and annual (A) and perennial (P) species (below) in years 1995, 2000 and 2005 present in each tree system (exclusively in pine, exclusively in birch and shared by both systems). This figure is available in colour online at wileyonlinelibrary.com

perennial species in 2005) compared to native birch canopies (between 47 and 73 per cent of perennial species). In the first case, the absence of annual species can be explained by the higher light interception of the conifer canopy and the presence of an important litter layer that prevented the root systems of these species from reaching the soil, as was described when conifer and broadleaved species were compared in the same area (Rozados et al., 2007). In the case of the birch tree, the presence of summer drought in the area favoured mortality for perennial species that were incorporated into the soil, leaving gaps that permitted the germination and rapid establishment of annual species, although their proportion was not as high as in the Mediterranean region (Mosquera-Losada et al., 2009).

Another anthropogenic factor that influenced variation in plant diversity was the management of the plantation with regard to the type of fertilisation (D or M) used in the system. With both types of fertilisers, there was a decrease in the plant $\alpha$ diversity expressed in the form of $\mathrm{S}$, and the Shannon Index $(\mathrm{H})$, with respect to the non-fertilised (NF) systems. The addition of fertiliser (NPK) and the use of pasture production through harvesting favoured the presence of sown species (Rodríguez et al., 1996; Mosquera and González, 2000; Rajaniemi, 2002), especially Dactylis glomerata. This Gramineae is characterised by strong growth in height, out-competing shorter species like Leguminae (clovers); these may even disappear from the system completely, thus resulting in an important decrease in the diversity and richness of species under these treatments (Mosquera-Losada et al., 2000; Rodríguez et al., 2001).

With regard to the factors related to the overstorey, numerous studies indicate that understorey vegetation is influenced by overstorey composition and structure through modifications of resource availability: light, water and soil nutrients and other effects such as the physical characteristics of the litter layer (Barbier et al., 2008). Light is commonly considered to be the major limiting factor of forest vegetation cover and/or richness (Barbier et al., 2008), and light penetration is affected by leaf size, specific leaf area, canopy form and deciduous leaf mass (Coomes and Grubb, 2000). In our region, the growth of the pine tree in terms of both height and diameter was greater than that of the native birch tree. This faster growth rate resulted in canopy closure 5 years after the beginning of the experiment (2000) in the systems established with pine trees. In our case, canopy closure caused a marked decrease in light in the pine tree plots and favoured the presence of litter, especially during the final year of the study (2005). In this situation, the seeds under the litter were deprived of light, and the seeds on top could not easily take root (Hamrick and Lee, 1987; Facelli and Pickett, 1991; Ellsworth et al., 2004). This caused a considerable decrease in the species richness and floristic diversity of the system. Species such as Cerastium glomeratum Thuill, Chenopodium album L., Agrostis capillaris L., Holcus lanatus L., Lolium perenne L., Trifolium repens $\mathrm{L}$., Plantago lanceolata L., Rumex acetosella L. and Daucus carota L. (Table I) virtually disappeared from the understorey vegetation because these plant species were unable to tolerate the deep shade beneath Pinus radiata. With canopy closure, the microclimate beneath the tree cover changes, reducing the interior temperature of the system and increasing the interception of rainfall by the trees (Papanastasis, 2004; Moreno et al., 2005; Mosquera-Losada et al., 2005). In our case, these two situations were emphasised when the canopy consisted of perennial species 
(Pinus radiata) and involved a decrease in the decomposition of organic material and its accumulation within the system (Marcos et al., 2007). As a consequence, greater acidification of the plots occurred, especially in those plots replanted with conifers (Barbier et al., 2008) in which the $\mathrm{pH}$ was already lower (Mosquera-Losada et al., 2006). Moreover, in our case, the results showed a lower acidification rate for those plots that received mineral fertiliser (M) exclusively as found by Mosquera-Losada et al. (2006). This could be explained by the lower growth rate of the tree cover and the decreased production of biomass, resulting in a reduced extraction of nutrients and an inferior acidification. This change in the $\mathrm{pH}$ of the systems could also have contributed to the reduction in $\alpha$ diversity (Schlenker, 1968). The area went from a high $\mathrm{pH}(6 \cdot 8)$ maintained over time due to potato cropping to a drop of at least one $\mathrm{pH}$ point in only a few years. This modifies the availability of nutrients (Mosquera-Losada et al., 2006) and can affect the competitive relationships between the different pasture species, favouring the presence of gramineae over the dicotyledonae, which have a greater cation content (Pinto et al., 2001) and, therefore, a greater need for cation extraction. On the other hand, and due to the importance of growth rate for the forest species used in our area (Galicia has one of highest potential forest growth rates in Europe), rapid change was produced in an area with a long tradition of managing liming materials and in which the established seed banks were more in agreement with these more acid conditions. For this reason, the graminoide grassland species habitually found in the scrublands typical of the region (Mosquera-Losada et al., 2009) and in soils with a pH lower than 5.0 did not appear. Buscardo et al. (2008) also suggests that afforestation represents a threat to semi-natural habitats biodiversity like grasslands.

In numerous articles, the variation in diversity along temperature and topographical gradients has been studied, comparing arboreal forestlands established in different areas of the same region and even across a whole country (Brockway, 1998, Gachet et al., 2007). In our case, $\beta$ diversity has been used with the objective of comparing effects on species composition that may be caused by the decision to establish one forest species or another. The results obtained in this study show important variation in the composition of species. As explained previously, the effects of the establishment of a dense plantation of a forest species such as Pinus radiata species on the ecosystem are important (decrease in light, variation in $\mathrm{pH}$, accumulation of needles in the soil, etc.); these effects resulted in variation in the floristic composition and, therefore, distancing from the initial characteristics of the system when compared with birch trees. As indicated, in the case of systems established with conifers, only four species were able to adapt to the new changes in the ecosystem (Dactylis glomerata, Senecio jacobea L., Elymus repens L. and Prunella vulgaris), while the establishment of birch trees, even after 11 years, led to less important disturbances and allowed species, such as Holcus lanatus, Holcus mollis L., Trifolium campestre Schreber, Trifolium repens, Rumex acetosella, and Daucus carota (up to a total of 13 species), to continue to form part of the understorey vegetation. But, the modifications introduced by the tree cover also favoured the appearance of some herbaceous species exclusively under one or another type of tree. Thus, species such as Illecebrum verticillatum, Stellaria media, Achillea millefolium L., Coleostephus myconis, Sonchus asper, Elymus repens L., Vicia sativa L., Linum bienne Miller and Polygonum aviculare appear to be associated with pine trees. Conversely, Lithodora prostata Loisel, Lepidium heterophyllum Bentham, Scleranthus annuus, Chamaemelum mixtum L., Hieracium pilosella L., Leontodon saxatilis Lam, Erodium moschatum (L.) ĹHér., Mentha suaveolens Ehrh, Lotus corniculatus L., Montia fontana L., Ranunculus repens L., Rhinanthus minor L. and Veronica agrestis L. appeared only under birch trees.

In conclusion, the establishment of a silvopastoral system with two forest species that are very different in terms of growth and canopy development introduced important modifications over the mid- and short-term. In the case of the soil, both systems caused acidification, but this effect was more important in the systems established with Pinus radiata, specially when the fertilisation type (sludge or NF) enhanced tree growth. Pasture production was drastically reduced in both established systems, negatively affecting its use for livestock production and, therefore, the output that the owner could achieve over a mid-term time frame. Pasture production was positively affected by fertilisation when tree canopy development did not reduce pasture response to fertiliser inputs at the start of the experiment. The diversity of both the species $(\alpha)$ and the habitat $(\beta)$ was notably reduced by the introduction of an conifer (Pinus radiata) compared to a native broadleaf species (Betula alba), being this effect more iportant in those fertilised treatments, which enhanced pine development (D and NF). This negative effect was obtained in a relatively short period of time in this study due to the high density of the established stand. Initial choice of forest species is highly relevant because a reduction in pasture production and important plant diversity losses can result in the short term. However, more long-term studies should be carried out in order to understand production and plant diversity responses to different canopies, with an emphasis on differences in tree types and density and fertilisation regimes in older stands.

\section{ACKNOWLEDGEMENTS}

The authors are grateful to CICYT and XUNTA for financial assistance, Escuela Politécnica Superior for facilities and to 
Divina Vázquez Varela, José Javier Santiago Freijanes, Aurora López Veiga, Teresa López Piñeiro, Pablo Fernández Paradela and Mónica García Fernández for their collaboration in the sampling and laboratory analyses of this study.

Research was funded in part by Educational, Science and Technology Ministry (CICYT) and autonomic regional government (Xunta de Galicia).

\section{REFERENCES}

Aguiar MR. 2005. Biodiversity in grasslands: Current changes and scenarios for the future. In Grasslands: Developments, Opportunities, Perspectives, Food and Agricultural Organization (FAO), Reynolds S, Frame J (eds). Science Publishers, Inc: Rome; 261-280.

Augusto L, Rangera J, Binkley D, Rothe A. 2002. Impact of several common tree species of European temperate forests on soil fertility. Annals of Forest Science 59: 233-253.

Barbier S, Gosselin F, Balandier P. 2008. Influence of tree species on understorey vegetation diversity and mechanisms involved-A critical review for temperate and boreal forests. Forest Ecology and Management 254: 1-15.

BOE (Spanish Official Bolletin) 01/11/1990 Real Decreto 1310/1990 29 de Octubre de 1990, que regula la utilización de los lodos de depuración (Royal Decree 1310/1990 29th October 1990, that regulates the use of sewage sludge). Ministerio Agricultura, Pesca y Alimentación, Madrid.

Brockerhoff EG, Ecroyd CE, Langer ER. 2001. Bidoversity in New Zealand plantation forests: Policy trends, incentives, and the state of our knowledge. New Zealand Journal of Forestry 46: 31-37.

Brockway DG. 1998. Forest plant diversity at local and landscape scales in the Cascade Mountains of southwestern Washington. Forest Ecology and Management 109: 323-341.

Buscardo E, Smith GF, Kelly DL, Freitas H, Iremonger S, Mitchel FJG, ÓDonoghue S, Mckee AM. 2008. The early effects of afforestation on biodiversity of grasslands in Ireland. Biodiversity and conservation 17: 1057-1072.

Calvo de Anta R, Macías F, Riveiro Cruz A. 1992. Aptitud agronómica de la provincia de La Coruña (cultivos, pino, roble, eucalipto y castaño). Diputación de La Coruña, Spain.

Castro P, González A, Prada D. 1990. Determinación simultánea de nitrógeno y fósforo en muestras de pradera. XXX Reunión Científica de la Sociedad Española para el Estudio de los Pastos; 200-207.

Colwell RK, Coddington JA. 1994. Estimating terrestrial biodiversity through extrapolation. Philosophical Transactions of the Royal Society of London 345: 101-118.

Coomes DA, Grubb PJ. 2000. Impacts of root competition in forests and woodlands: A theoretical framework and review of experiments. Ecological Monographs 70: 171-207.

Dyrness CT. 1973. Early stages of plant succession following logging and burning in the western cascades of Oregon. Ecology 54: 57-69.

EC. 2004. In support of the Communication from the Commission to the Council and the European Parliament in the implementation of the EU Forestry Strategy. Draft Commision Staff Working Document.

EEA. 2003. Europés environment: The third assessment. EEA, Copenhagen. http://reports.eea.europa.eu/environmental_assessment_report_2003_10/ en/kiev_chapt_00.pdf

Ellsworth J, Harrington R, Fownes J. 2004. Seedling emergence, growth, and allocation of oriental bittersweet: Effects of seed input, seed bank, and forest floor litter. Forest Ecology and Management 190: 255-264.

Facelli JM, Pickett STA. 1991. Plant litter: Light interception and effects on an oldfield plant community. Ecology 72: 1024-1031.

FAO-ISRIC-ISSS. 1998. World Referent Base for Soil Resources. World Soil Resources Reports 84, Rome.

Fernández-Núñez E, Mosquera-Losada MR, Rigueiro-Rodríguez A. 2007. Economic land evaluation of different land use alternatives: Forest, grassland and silvopastoral systems. Grassland Science in Europe 12: $508-511$.
Ferris R, Peace AJ, Humphrey JW, Broome AC. 2000. Relationships between vegetation, site type stand structure in coniferous plantations in Britain. Forest Ecology and Management 136: 35-51.

Frank D, Finckh M. 1997. Impactos de las plantaciones de pino de oregón sobre la vegetación y el suelo en la zona centro-sur de Chile. Revisa chilena de historia natural 70: 191-211.

Gachet S, Leduc A, Bergeron Y, Nguyen-Xuan T, Tremblay F. 2007. Understory vegetation of boreal tree plantations: Differences in relation to previous land use and natural forests. Forest Ecology and Management 242: 49-57.

Grime J. 1982. Estrategias de adaptación de las plantas y procesos que controlan la vegetación. Limusa, México.

Hamrick JL, Lee JM. 1987. Effect of soil surface topography and litter cover on the germination, survival and growth of musk thistle (Carduus nutans). American Journal of Botany 74: 451-457.

IFN. 1998. III Inventario Forestal de España. Dirección General de Conservación de la Naturaleza. Ministerio de Medio Ambiente, Madrid.

Lande R. 1996. Statistic and partitioning of species diversity and similarity among multiple communities. Oikos 76: 5-13.

Magurran AE. 2004. Measuring Biological Diversity. Blackwell Publishing: Malden.

MAPA. 2006. Anuario de estadística agraria. Ministerio de Medio Ambiente Pesca y Alimentación, Madrid.

Marcos JE, Marcos E, Taboada A, Tárrega R. 2007. Comparison of community structure and soil characteristics in different aged Pinus sylvestris plantation and a natural pine forest. Forest Ecology and Management 247: 35-42.

Michelsen A, Lisanework N, Friis I, Holst N. 1996. Comparisons of undersoty vegetation and soil fertility in plantations and adjacent natural forests in the Ethiopian highlands. Journal applied ecology 33: 627-642.

Moreno CE. 2001. Métodos para medir la biodiversidad. M\&T-Manuales y Tesis SEA, Spain.

Moreno G, Obrador J, García E, Cubera E, Montero MJ, Pulido F. 2005. Consequences of dehesa management on tree-understorey interactions. In Silvopastoralism and Land Sustainable Management, Mosquera-Losada MR, McAdam J, Rigueiro-Rodríguez A (eds). CABI Publishing: London; 263-266.

Moreno G, Obrador JJ, García E, Cubera E, Montero MJ, Pulido F, Dupraz C. 2007. Driving Competitive and Facilitative Interactions in Oak Dehesas through Management Practices. Agroforestry Systems 70: 2540 .

Mosquera MR, González A. 1998. Effect of annual stocking rates in grass and maize+rye systems on production by dairy cows. Grass and Forage Science 53: 95-108.

Mosquera MR, González A. 2000. Fertilisación nitrogenada y potásica en pradera mixta: I. Efecto sobre la composición botánica, el contenido en proteína y el nivel de macroelementos. Pastos XXX: 241-260.

Mosquera-Losada MR, González-Rodríguez A, Rigueiro-Rodríguez A. 2000. Sward quality affected by different grazing pressures on dairy systems. Journal of Range Management 53: 603-610.

Mosquera-Losada MR, Pinto-Tobalina M, Rigueiro-Rodríguez A. 2005. The herbaceous component in temperate silvopastoral systems. In Silvopastoralism and Land Sustainable Management, Mosquera-Losada MR, McAdam J, Rigueiro-Rodríguez A (eds). CABI Publishing: Wallingford; 93-101.

Mosquera-Losada MR, Fernández-Núñez E, Rigueiro-Rodríguez A. 2006. Pasture, tree and soil evolution in silvopastoral systems of Atlantic Europe. Forest Ecology and Management 232: 135-145.

Mosquera-Losada MR, Rodríguez-Barreira S, López-Díaz ML, FernándezNúñez E, Rigueiro-Rodríguez A. 2009. Biodiversity and silvopastoral system use change in very acid soils. Agriculture, Ecosystems and Environment 131: 315-324.

Official Journal of the European Communities 2002. Decission $n^{\circ} 1600 /$ 2002/EC of the European Parliament and of the Council of 22 July 2002. http://biodiversity-chm.eea.europa.eu/convention/F1117799202/ F1122843896 (Cited 30 October 2009).

Palviainen M, Finér L, Kurka AM, Mannerkoski H, Piirainen S, Starr M. 2004. Release of potassium, calcium, iron and aluminium from Norway spruce, Scots pine and silver birch logging residues. Plant and Soil 259: $123-136$. 
Papanastasis VP. 2004. Vegetation degradation and land use changes in agrosilvopastoral systems. In Sustainability of Agrosilvopastoral Systems (Dehesa, Montados) Advances in GeoEcology 37, Schnabel S, Ferreira A (eds). Catena Verlag: Reiskirchen; 1-12.

Paritsis J, Aizen MA. 2008. Effects of exotic conifer plantations on the biodiversity of understory plants, epigeal beetles and birds in Nothofagus dombeyi forests. Forest ecology and management 255 : 1575-1583.

Pearson CJ, Ison RL. 1987. Vegetative Growth in Agronomy of Grassland Systems. Cambridge University Press: Cambridge.

Pinto M, Besga G, Rodriguez M, Fisher G. 2001. Chemical composition of species-rich pastures. REU Technical Series (FAO) 64, Rome.

Porta Casanellas J, Roquero De Laburo C, López-Acevedo M. 2003. Edafología para la agricultura y el medio ambiente. Mundi Prensa: Madrid.

Raffaele E, Schlichter T. 2000. Efectos de las plantaciones de pino ponderosa sobre la heterogeneidad de micrositios en estepas del noroeste patagónico. Ecología austral 10: 149-155.

Rajaniemi TK. 2002. Why does Fertilisation reduce plant species diversity? Testing three competition-based hypotheses. Journal of Ecology 90: 316324.

Rigueiro-Rodríguez A, Fernández-Núñez E, González-Hernández P, McAdam JH, Mosquera-Losada MR. 2009. Agroforestry systems in Europe: Productive, ecological and social perspectives. In Agroforestry in Europe Current Status and Future Prospects, Rigueiro-Rodríguez A, McAdam JH, Mosquera-Losada MR (eds). Springer: Berlin; 43-65.

Rodríguez M, García R, Moro A, Calleja A. 1996. Los prados permanentes en la economía de la montaña leonesa. Pastos XXVI: 25-27.
Rodríguez M, Gómez-Sal A, García R, Moro A, Calleja A. 2001. Relaciones entre producción, diversidad y riqueza de especies en prados fertilizados. In Biodiversidad en pastos. Compobell Murcia: Spain; 175-180.

Rozados MJ, González-Hernández MP, Silva Pando FJ. 2007. Pasture production under different tree species and densities in an Atlantic silvopastoral system. Agroforestry Systems 70: 53-62.

SAS. 2001. SAS/Stat Usérs Guide: Statistics. SAS Institute Inc.: Cary.

Schipper, ECT. 1996. Biodiversity and community structure in Pinus radiata (D.Don) plantations in Central North Island. Unpubl. B.For.Sc, dissertation, School of Forestry, University of Canterbury: Christchurch; 39 pp.

Schlenker G. 1968. Experiments in culture with plants of the forest ground flora, subjected to different degrees of acidity and variations in the form of nitrogen supply. Acta Oecologica 3: 7-27.

Sibbald A. 1996. Silvopastoral systems on temperate sown pastures: A personal perspective. In Western European Silvopastoral Systems, Étienne M (ed.). INRA: Paris; 23-36.

Shannon CE, Weaver W. 1949. The Mathematical Theory of Communication. Univ. Illinois Press: IL.

Terradas J. 2001. Ecología de la vegetación: de la ecofisiología de las plantas a la dinámica de comunidades y paisajes. Omega: Barcelona.

VARIAN. 1989. Analytical Methods. VARIAN: Mulgrave, Victoria.

Wallace HL, Good JEG, Williams TG. 1992. The effects of afforestation on upland plant communities: An application of the British National Vegetation Classification. Journal of Applied Ecology 29: 180-194.

Wallace HL, Good JEG. 1995. Effects of afforestation on upland plant communities and implications for vegetation management. Forest Ecology and Management 79: 29-46.

Whitehead DC. 1995. Grassland Nitrogen. CAB international: Wallingford. 